\title{
Mobile Learning Adoption: A Systematic Review of the Technology Acceptance Model from 2017 to 2020
}

\author{
https://doi.org/10.3991/ijet.v16i05.18093 \\ Rawan A. Alsharida, Maytham M. Hammood \\ Tikrit University, Tikrit, Iraq \\ Mostafa Al-Emran ( $₫)$ \\ The British University in Dubai, Dubai, UAE \\ mustafa.n.alemran@gmail.com
}

\begin{abstract}
Numerous review studies were conducted in the past to understand the applicability of the technology acceptance model (TAM) in mlearning context by examining several issues. Although each of those studies provided a valuable synthesis of TAM, further issues are still uncovered and call for further research. Therefore, this research aims to systematically review the existing TAM-based m-learning studies through the analysis of various issues, including the factors affecting the m-learning adoption, research methods, TAM progress over publication years, online databases, active countries, and sample size. Out of 458 articles collected, a total of 64 studies published between 2017 and 2020 were critically analyzed. The main results indicated that self-efficacy is the most frequent factor affecting the m-learning adoption, followed by subjective norm, enjoyment, mobile anxiety, facilitating conditions, social influence, innovativeness, and satisfaction, respectively. Additionally, most of the analyzed studies have relied on questionnaire surveys in collecting their empirical data. Although it was developed in 1989, the results showed that the number of TAM-based m-learning studies is increasing year by year, which in turn, increases the credibility of the model in explaining the users' intentions towards technology adoption. We have also discussed the contributions of this systematic review and the implications that it could yield for future attempts.
\end{abstract}

Keywords-M-learning, technology acceptance model, systematic review

\section{Introduction}

The increasing use of mobile devices through Internet networks has brought several opportunities for education [1], [2]. It is expected that the rate of mobile Internet penetration will reach $71 \%$ of the entire world population by 2025 [3]. Mobile learning (m-learning) has become an appealing research trend for many scholars [4], [5]. This stems from the fact in which m-learning affords learners with the capability to learn at "anytime anywhere" settings by allowing the availability of learning content over mobile networks and accessing such content through different devices, such as smartphones and tablets [6], [7]. Given the paramount features of m-learning in edu- 
cation, a growing body of literature was carried out to examine the use of m-learning in learning activities at one side, and the determinants (i.e., factors) affecting its adoption on the other side [8]-[10].

In order to understand the factors affecting the adoption of m-learning, a number of theoretical models were used, including the "theory of reasoned action (TRA)" [11], "technology acceptance model (TAM)" [12], "unified theory of acceptance and use of technology (UTAUT)" [13], and "theory of planned behavior (TPB)" [14], among many others. Among those, the TAM was considered as one of the most frequently used theoretical models for predicting the adoption of several technologies due to its simplicity, adaptability, and soundness [15]. More specifically, the TAM was recently found as the most frequently theoretical model used in understanding the m-learning adoption [16]. It was also argued that TAM has an efficient explanatory power and has been successfully validated through several measurement scales [17]. The strong empirical support of TAM to its core variables, namely "perceived ease of use" and "perceived usefulness" in examining the individuals' adoption of several technologies, increased the applicability of the model across different disciplines [18]-[20].

In line with the surveyed literature, a number of review studies were carried out in the past to understand the applicability of TAM in m-learning context by examining several issues. In spite of the fact that each of those studies provided a valuable synthesis of TAM, further issues are still uncovered and call for further research. For instance, despite the increasing number of studies regarding the explanation of the factors affecting the m-learning adoption or acceptance, reviewing and synthesizing these factors in a systematic and comprehensive way is still scarce. The understanding of these factors and their significant role in m-learning systems adoption is believed to facilitate the employment of such systems across different contexts. Therefore, this study aims at systematically reviewing the existing TAM-based m-learning studies to identify the factors affecting the m-learning adoption. Besides, this systematic review also intends to examine the surveyed studies by considering other issues, including research methods, TAM progress over publication years, online databases, active countries, and sample size. Drawing on that, the following research questions were formulated:

RQ1: What are the most frequent factors affecting the m-learning adoption?

RQ2: What are the dominant research methods in the analyzed TAM-based mlearning studies?

RQ3: What is the progress of TAM-based m-learning studies over publication years?

RQ4: What are the leading online databases in which the TAM-based m-learning studies are indexed?

RQ5: What are the most active countries in conducting TAM-based m-learning studies?

RQ6: What is the research sample size used in the analyzed TAM-based mlearning studies? 


\section{Related Work}

A number of review studies were carried out during the last decade to review the TAM on the one hand and the m-learning adoption, on the other hand. Among these studies, Liu et al. [21] reviewed the m-learning literature to understand the existing level of m-learning and to determine the factors affecting its adoption. Chang et al. [22] conducted a review study using a bibliometric analysis method to analyze the growth of TAM-based studies. In spite of the significant results provided, the study was almost descriptive in nature and did not offer sufficient implications. Chen et al. [23] carried out a review study to understand the employment of TAM and its extension across different application areas. However, the study was limited to the analysis of the application areas in which the TAM was employed. Shuib et al. [24] conducted a review study to analyze mobile phone usage, underlying applications, their negative impact, pervasive computing, and mobile pervasive learning technologies. Besides, Navarro et al. [25] conducted another review study to analyze the factors affecting the m-learning adoption. Al-Emran et al. [8] conducted a systematic review to analyze the employment of TAM in m-learning context through the examination of several issues, including research purposes, educational levels, publication years, active countries, methods, and disciplines. Kumar and Chand [16] conducted a systematic review to analyze the m-learning adoption through the examination of several issues, including publication trends, theoretical models, and factors influencing m-learning adoption. Table 1 lists the details of the previous relevant review studies.

Despite the fact that some of the previous reviews have analyzed the factors affecting the m-learning adoption [16], [21], [25], none of these studies have analyzed the factors in a comprehensive and systematic way. For instance, Liu et al. [21] have analyzed the factors from the lenses of three themes, including consumer, technology user, and learner. In addition, Navarro et al. [25] have classified the analyzed factors into three categories, including technological, pedagogical, and students' aspects. Besides, Kumar and Chand [16] have considered the original/core factors of the analyzed theoretical models in the analysis process. It can be observed that none of the previous reviews have emphasized on the external factors affecting the m-learning adoption in a systematic and comprehensive manner.

Drawing upon the existing literature, this systematic review is an attempt to extend the recent systematic reviews in the domain [8], [16] with recent studies published between 2017 and 2020. In contrast with the previous reviews, the current systematic review attempts to analyze the external factors affecting the m-learning adoption rather than simply analyzing the original factors of the theoretical models. This study also intends to analyze the existing studies through other perspectives, including research methods, progress of TAM over publication years, online databases, active countries, and sample size. 
Table 1. Previous relevant review studies.

\begin{tabular}{|c|c|c|c|c|c|}
\hline Source & Type & \begin{tabular}{|c|}
$\begin{array}{c}\text { Coverage } \\
\text { years }\end{array}$ \\
\end{tabular} & $\begin{array}{c}\text { No. of analyzed } \\
\text { studies }\end{array}$ & Discipline & Issues analyzed \\
\hline [21] & $\begin{array}{l}\text { Literature } \\
\text { review }\end{array}$ & $2005-2009$ & 21 & General & $\begin{array}{l}\text { To determine the existing level } \\
\text { of m-learning and the factors } \\
\text { influencing its adoption. }\end{array}$ \\
\hline [22] & $\begin{array}{l}\text { Literature } \\
\text { review }\end{array}$ & 1991-2009 & 689 & $\begin{array}{l}\text { Computer science, } \\
\text { information systems, } \\
\text { information science, } \\
\text { management and } \\
\text { business, and library } \\
\text { science. }\end{array}$ & $\begin{array}{l}\text { To analyze the growth of litera- } \\
\text { ture and citations, document } \\
\text { type, countries, subject areas, } \\
\text { keywords, and distribution of } \\
\text { journal papers. }\end{array}$ \\
\hline [23] & Review & N/A & 24 & N/A & $\begin{array}{l}\text { To understand the employment } \\
\text { of TAM and its extension across } \\
\text { different application areas. }\end{array}$ \\
\hline [24] & Review & N/A & 55 & N/A & $\begin{array}{l}\text { To analyze the mobile phone } \\
\text { usage, associated applications, } \\
\text { their negative impact, pervasive } \\
\text { computing, and mobile pervasive } \\
\text { learning technologies. }\end{array}$ \\
\hline [25] & $\begin{array}{l}\text { Literature } \\
\text { review }\end{array}$ & N/A & N/A & General & $\begin{array}{l}\text { To analyze the factors affecting } \\
\text { the m-learning adoption and } \\
\text { classify them into three catego- } \\
\text { ries, including technological, } \\
\text { pedagogical, and students' } \\
\text { aspects. }\end{array}$ \\
\hline [8] & $\begin{array}{l}\text { Systematic } \\
\text { review }\end{array}$ & 2006-2018 & 87 & $\begin{array}{l}\text { IT and computer } \\
\text { science, foundation } \\
\text { program, engineer- } \\
\text { ing, medicine, busi- } \\
\text { ness and manage- } \\
\text { ment, and geogra- } \\
\text { phy. }\end{array}$ & $\begin{array}{l}\text { To analyze the research purpos- } \\
\text { es, educational levels, publica- } \\
\text { tion years, active countries, } \\
\text { methods, and disciplines. }\end{array}$ \\
\hline [16] & $\begin{array}{l}\text { Systematic } \\
\text { review }\end{array}$ & $2009-2017$ & 27 & General & $\begin{array}{l}\text { To analyze the publication } \\
\text { trends, theoretical models, and } \\
\text { factors influencing m-learning } \\
\text { adoption. }\end{array}$ \\
\hline $\begin{array}{c}\text { Current } \\
\text { study }\end{array}$ & $\begin{array}{l}\text { Systematic } \\
\text { review }\end{array}$ & $2017-2020$ & 64 & General & $\begin{array}{l}\text { To analyze the factors influenc- } \\
\text { ing the m-learning adoption, } \\
\text { research methods, progress of } \\
\text { TAM over publication years, } \\
\text { online databases, active coun- } \\
\text { tries, and sample size. }\end{array}$ \\
\hline
\end{tabular}

\section{$3 \quad$ Method}

This research employs a systematic review method for reviewing the research studies published on the use of TAM in m-learning context. We followed the well-known principle guidelines that were put forward by Kitchenham and Charters [26] in conducting systematic review studies, and other relevant systematic reviews in the domain [8], [27]-[29]. These guidelines were strictly followed as per the following subsections. 


\subsection{Inclusion and exclusion criteria}

The articles that would be involved in the critical analysis should address the inclusion and exclusion criteria provided in Table 2.

Table 2. Inclusion and exclusion criteria.

\begin{tabular}{|l|l|}
\hline \multicolumn{1}{|c|}{ Inclusion Criteria } & \multicolumn{1}{c|}{ Exclusion Criteria } \\
\hline Must contain m-learning as an essential technology. & TAM-based studies but not m-learning. \\
\hline Must contain the TAM as a theoretical model. & M-learning-based studies but not TAM. \\
\hline Must be written in English language only. & Written in other languages. \\
\hline Must involve educational activities. & $\begin{array}{l}\text { M-learning studies that were conducted in non- } \\
\text { educational activities. }\end{array}$ \\
\hline Accessibility to full-text articles. & Inaccessibility to full-text articles. \\
\hline Must be published between 2017 and 2020. & Published earlier than 2017. \\
\hline
\end{tabular}

\subsection{Data sources and search strategies}

The research studies used in the current systematic review were collected between December 2019 and January 2020. Several online databases were used to search for the targeted studies, including "Springer", "ScienceDirect", "Taylor \& Francis", "Wiley", "IEEE", and "Emerald". The search terms include the keywords (("mobile learning" OR “m-learning”) AND (“technology acceptance model” OR “TAM")). In line with the inclusion criteria, the time span for the search was set to include studies published between January 2017 and January 2020. By using the specified keywords and time span, a total of 458 articles were collected. Of those, 10 articles were found as duplicates, and hence, they were eliminated. As a result, the total number of remaining articles becomes 448. The search and refinement stages were undertaken according to the Preferred Reporting Items for Systematic Reviews and MetaAnalysis (PRISMA) [30]. The inclusion and exclusion criteria were applied for each article in order to confirm its relevance to the research questions. Consequently, a total of 64 studies were found to meet the inclusion criteria, and therefore, these articles were included in the final stage of data analysis. Figure 1 describes the entire review process through the PRISMA flowchart. 




Fig. 1. PRISMA flowchart.

\subsection{Data coding and analysis}

In line with the research questions of this study, several attributes were coded and analyzed. These attributes include

a) External factors to TAM

b) Research methods (e.g., questionnaires, interviews, mixed methods, etc.)

c) Publication year

d) Online databases (e.g., Springer, ScienceDirect, IEEE, etc.)

e) Active countries, and

f) The sample size of participants. 


\section{$4 \quad$ Results and Discussion}

The research questions of this study were addressed under the following subsections:

\subsection{Factors affecting m-learning adoption}

Over the 64 analyzed studies, a total of 23 external factors were determined. It is imperative to mention that only the factors that appeared at least twice in the analyzed studies were considered. Unlike the previous systematic review which considered the core factors of the theoretical models in the analysis process [16], the current systematic review only considered the external factors to the original constructs of TAM (i.e., "perceived usefulness", "perceived ease of use", "attitude towards use", "behavioral intention", and "actual use"). Figure 2 illustrates the analysis of the external factors affecting the adoption of m-learning. It can be seen that self-efficacy is the most frequent factor affecting the m-learning adoption in 17 studies. This is followed by subjective norm with ten studies, enjoyment with nine studies, mobile anxiety and facilitating conditions together with seven studies, social influence and innovativeness together with five studies, satisfaction with four studies, and trust, technological complexity, and perceived behavioral control together with three studies. The rest of the depicted factors appeared in two studies only. These results are in agreement with the previous TAM-based e-learning studies [31], in which self-efficacy and subjective norm were the most frequent factors affecting the e-learning adoption through the lenses of TAM.

Concerning the self-efficacy, these results suggest that learners who have higher m-learning self-efficacy are more likely to employ the m-learning systems in their learning activities. In terms of subjective norm, these results suggest that if a student perceives that people who are important to him/her (e.g., instructors or colleagues) think that he/she should use the m-learning system, then the student will consider their beliefs into his/her own beliefs, and perceives the system as useful and easy to use for learning activities. 


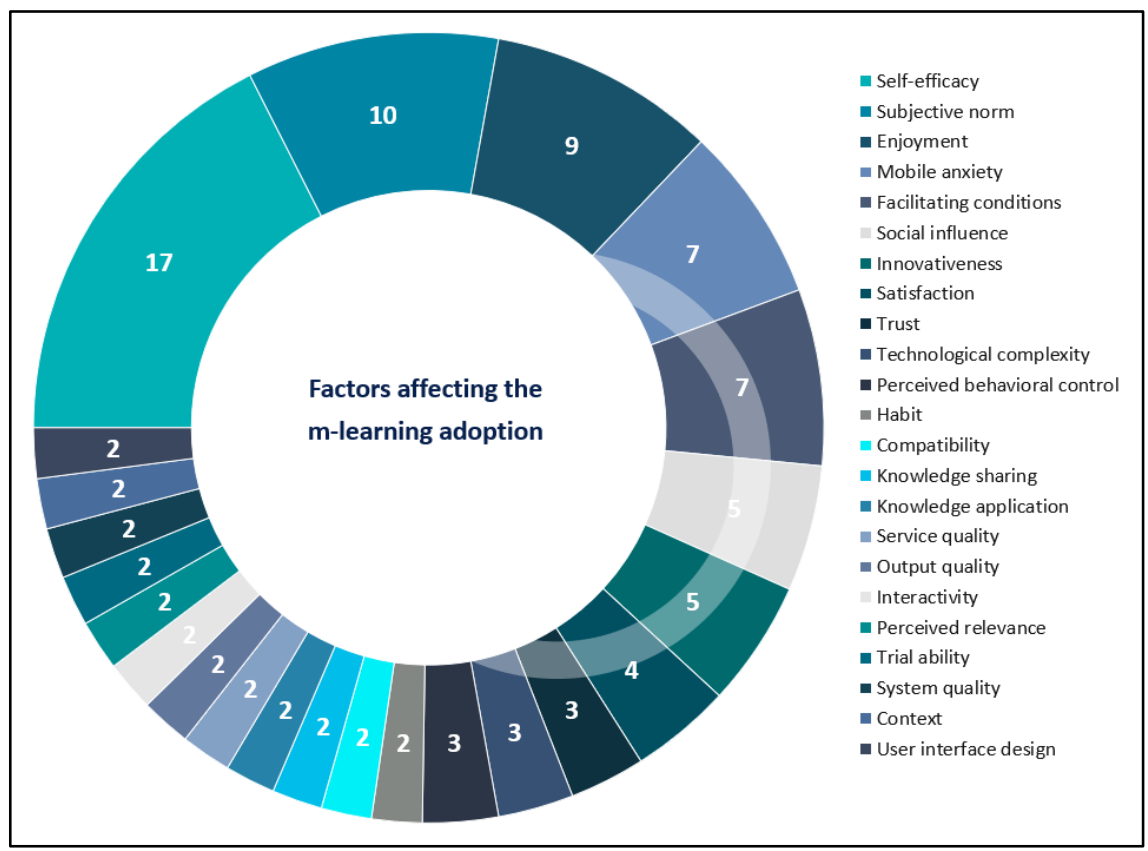

Fig. 2. Factors analysis.

\subsection{Distribution by research methods}

As shown in Figure 3, the selected articles were also analyzed according to the employed research methods. It can be seen that $81 \%$ of the analyzed articles $(\mathrm{N}=52)$ have primarily relied on questionnaire surveys for collecting the empirical data. This is followed by mixed methods (i.e., questionnaire surveys and interviews) with $11 \%$ and interviews with $5 \%$. These results confirm the results observed in previous $\mathrm{m}$ learning-related systematic reviews [8], [27], which pointed out that questionnaire surveys were the predominant techniques for collecting data. The dominant employment of questionnaire surveys for data collection is attributed to two significant reasons. First, questionnaire surveys can effectively and quantitatively analyze the respondents' intentions [32]. Second, these tools can appropriately identify the correlations among the constructs in the theoretical model [33]. 


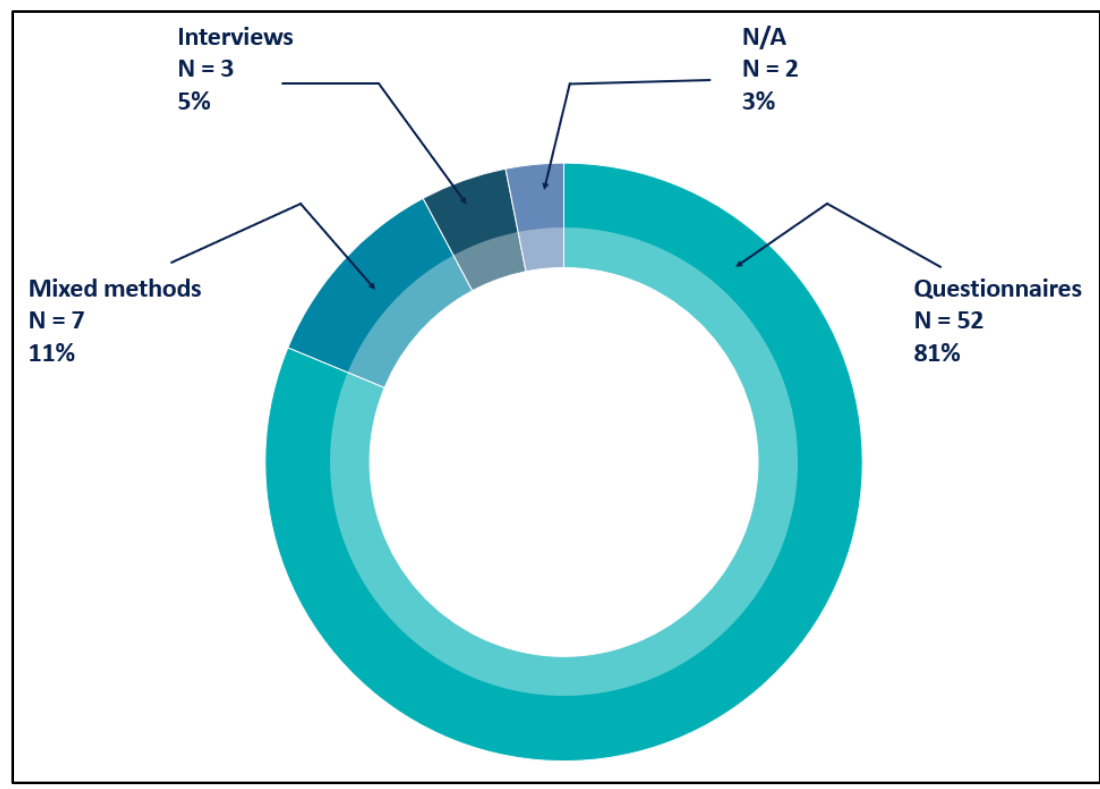

Fig. 3. Distribution by research methods.

\subsection{Distribution by publication years}

Concerning the publication year, Figure 4 shows the publication history for the analyzed studies. As depicted, the publications are ranged between 2017 and 2020, and the basis for this range stems from the search period for the analyzed articles. It can be seen that the number of publications has been increased from 18 studies in 2017 to 28 studies in 2019. In comparison with the analysis of the historical progress of TAM in a recent systematic review [8], this study provides evidence through which the number of TAM-based m-learning studies has been increased from 2006 [8] to 2019 (current study). The significant increase of these studies stems from several angles. First, the popularity of TAM in explaining the students' adoption of m-learning systems. Second, the increasing interest of scholars in examining the factors influencing the m-learning adoption across various contexts and subjects. It is important to report that the number of TAM-based m-learning studies is only one in 2020. This could be attributed to the fact in which the search range of the selected articles was undertaken between December 2019 and January 2020, and many articles are still not published yet. 


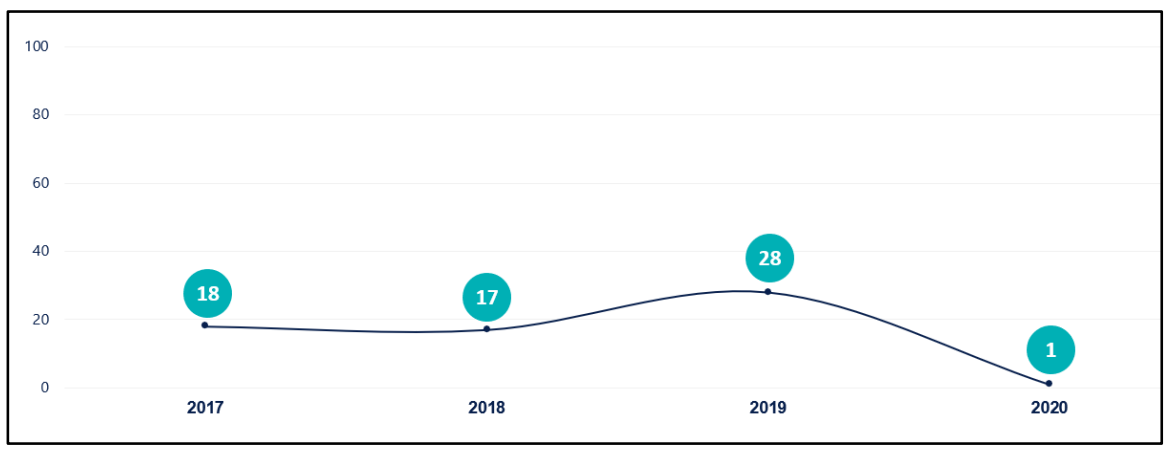

Fig. 4. Publication history for the analyzed studies.

\subsection{Distribution by online databases}

The selected studies were also classified according to the online databases in which these studies were indexed. Figure 5 describes the distribution of the selected studied according to the online databases. It can be observed that the majority of the analyzed studies were indexed in Springer $(\mathrm{N}=20)$. This is followed by ScienceDirect $(\mathrm{N}=$ $16)$, Taylor \& Francis $(\mathrm{N}=13)$, Wiley $(\mathrm{N}=7)$, IEEE $(\mathrm{N}=6)$, and Emerald $(\mathrm{N}=2)$. Finding the suitable online databases for articles collection is sometimes challenging for junior scholars and postgraduate students. Therefore, it is believed that these results would assist scholars in finding the appropriate databases and collecting the relevant research articles in the future.



Fig. 5. Distribution by online databases. 


\subsection{Distribution by countries}

Figure 6 depicts the prevalence of TAM-based m-learning studies across the globe. It can be noticed that most of the selected studies were conducted in China $(\mathrm{N}=15)$. This is followed by Spain $(\mathrm{N}=8)$, Taiwan $(\mathrm{N}=6)$, USA and Malaysia with four studies each, Iran and some European countries with three studies each, and Turkey, Singapore, Pakistan, KSA, and Italy with two studies each. The rest of the depicted countries appeared to have only one study each. These results contradict with the results noticed in previous related m-learning studies [8], [34], which indicated that Taiwan was the most frequent country in conducting relevant studies. This contradiction might be attributed to the differences in the inclusion and exclusion criteria of the selected studies. It can also be attributed to the differences in the underlying theoretical models of the selected studies. In addition, the increasing number of m-learning studies in China might stem from the growing number of smartphone users' penetration in China from 56\% in 2017 to $63.3 \%$ in 2019 [35].



Fig. 6. Distribution by countries.

\subsection{Distribution by sample size}

The identification of sample size is an essential task for empirical research studies. Insufficient and inappropriate sample sizes can affect the accuracy and quality of research studies [36]. Accordingly, this review study classified the selected articles according to the sample size used in each article. Figure 7 demonstrates the distribution of the analyzed articles according to the sample size used. It can be noticed that $30 \%$ of the analyzed articles have relied on a sample size ranges between 101 to 200 in conducting the empirical studies. This is followed by 201 to 300 with $19 \%$ and 10 to 100 with $17 \%$. It can also be noticed that the number of larger sample sizes is rela- 
tively small as compared with the number of small ones. Building upon small sample sizes might affect the generalization of results to the entire population.

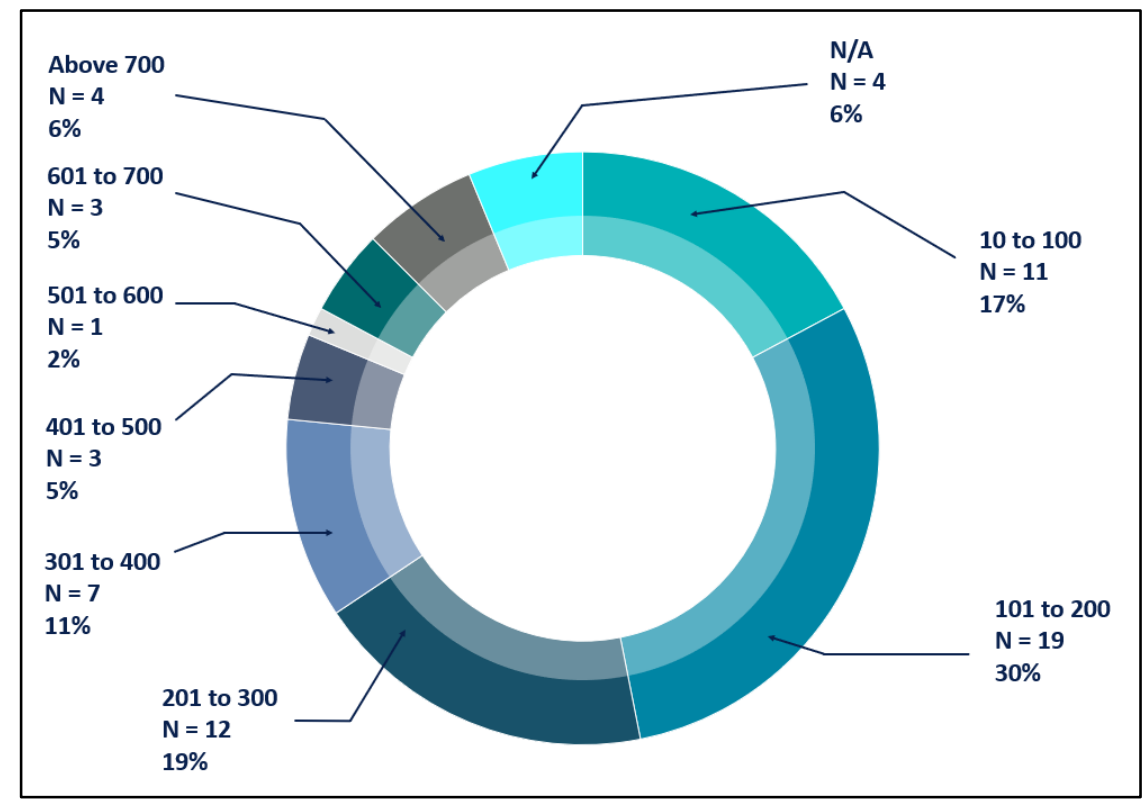

Fig. 7. Distribution by sample size.

\section{Conclusion}

\subsection{Research contributions and implications for future research}

This section tackles the contributions of the current systematic review and the implications that it could yield for future attempts. First, the identification of the most frequent factors affecting the m-learning adoption can help in building a general model for explaining the m-learning adoption regardless of the contexts and subjects. In that, further research could extend the TAM with the most frequent factors identified in this study in an attempt to build a comprehensive model for m-learning adoption. This is the same procedure followed in previous studies in building a comprehensive TAM for explaining the e-learning adoption [31], [37]. Second, it has been observed that most of the analyzed studies have relied on questionnaire surveys in collecting their empirical data. Further attempts can focus on the use of mixed methods, including surveys and interviews in collecting data. The use of mixed methods can help in better understanding the respondents' perceptions quantitatively and qualitatively.

Third, it has been noticed that the number of TAM-based m-learning studies is increasing year by year. Although it was developed in 1989, these results increase the credibility of the TAM in m-learning domain and its future applicability across various empirical studies. In line with the continuous effective use of TAM, further re- 
search could keep using the model in explaining the users' intentions towards any technology. Fourth, the study also identified the online databases in which the TAMbased m-learning studies were indexed. This finding would assist junior scholars and postgraduate students in finding the suitable databases and collecting the relevant articles. Fifth, a number of countries were identified according to their involvement in conducting TAM-based m-learning studies. This finding could assist scholars in conducting further empirical studies in the non-listed countries and examining the factors affecting the m-learning adoption in such countries. Sixth, it has been observed from the results that many of the analyzed studies were conducted with relatively small sample sizes. This might stem from the nature of the study in general, and subjects and contexts in particular. In order to determine the required sample size in any empirical study, scholars might refer to two different sources. The first has specified the population size and the corresponding sample size to that population [38]. The second is the use of the $\mathrm{G}^{*}$ Power tool by identifying the number of predictors in the theoretical model [39].

\subsection{Limitations and directions for future work}

This section discusses the limitations of the present study and suggests possible future research directions. Although the current systematic review provided an essential recapitulation of the TAM-based m-learning studies, it also posits some limitations that need to be discussed. First, this study has concentrated on a specific number of databases concerning the articles collection, which in turn, could reduce the amount of retrieved and analyzed articles. To handle this limitation, future trials could focus on retrieving articles from the Web of Science and Scopus as these two databases contain a vast amount of articles. Second, it was beyond the scope of this study to involve the $\mathrm{m}$-learning studies that were conducted in non-educational environments. Thus, further research could involve the m-learning studies that were conducted in noneducational settings to further enlighten the existing results.

\section{References}

[1] M. Al-Emran, "Mobile learning during the era of COVID-19," Rev. Virtual Univ. Católica del Norte, no. 61, pp. 1-2, 2020. https://doi.org/10.35575/rvucn.n61a1

[2] S. I. Malik and M. Al-Emran, "Social Factors Influence on Career Choices for Female Computer Science Students," Int. J. Emerg. Technol. Learn., vol. 13, no. 5, pp. 56-70, 2018. https://doi.org/10.3991/ijet.v13i05.8231

[3] GSMA, "The mobile economy," 2018. https://www.gsma.com/mobileeconomy/wpcontent/uploads/2018/02/The-Mobile-Economy-Global-2018.pdf.

[4] M. Al-Emran, Y. A. Alkhoudary, V. Mezhuyev, and M. Al-Emran, "Students and Educators Attitudes towards the use of M-Learning: Gender and Smartphone ownership Differences," Int. J. Interact. Mob. Technol., vol. 13, no. 1, pp. 127-135, 2019. https://doi.org/ 10.3991/ijim.v13i01.9374

[5] S. I. Malik, M. Al-Emran, R. Mathew, R. M. Tawafak, and G. AlFarsi, "Comparison of ELearning, M-Learning and Game-based Learning in Programming Education-A Gendered 
Analysis,” Int. J. Emerg. Technol. Learn., vol. 15, no. 15, pp. 133-146, 2020. https://doi. org/10.3991/ijet.v15i15.14503

[6] M. Alshurideh, B. Al Kurdi, S. A. Salloum, I. Arpaci, and M. Al-Emran, "Predicting the actual use of m-learning systems: a comparative approach using PLS-SEM and machine learning algorithms,” Interact. Learn. Environ., 2020. https://doi.org/10.1080/10494820.20 $\underline{20.1826982}$

[7] M. Al-Emran, V. Mezhuyev, and A. Kamaludin, “An Innovative Approach of Applying Knowledge Management in M-Learning Application Development: A Pilot Study,” Int. J. Inf. Commun. Technol. Educ., vol. 15, no. 4, pp. 94-112, 2019. https://doi.org/10.4018/iji cte. 2019100107

[8] M. Al-Emran, V. Mezhuyev, and A. Kamaludin, "Technology Acceptance Model in Mlearning context: A systematic review," Comput. Educ., vol. 125, pp. 389-412, 2018. https ://doi.org/10.1016/j.compedu.2018.06.008

[9] M. Al-Emran, V. Mezhuyev, and A. Kamaludin, "Towards a conceptual model for examining the impact of knowledge management factors on mobile learning acceptance," Technol. Soc., vol. 61, 2020. https://doi.org/10.1016/j.techsoc.2020.101247

[10] M. Al-Emran and V. Mezhuyev, "Examining the Effect of Knowledge Management Factors on Mobile Learning Adoption Through the Use of Importance-Performance Map Analysis (IPMA)," in International Conference on Advanced Intelligent Systems and Informatics, 2019, pp. 449-458. https://doi.org/10.1007/978-3-030-31129-2_41

[11] M. Fishbein and I. Ajzen, "Belief, attitude, intention and behaviour: An introduction to theory and research," Read. MA AddisonWesley, no. August, p. 480, 1975, doi: $10.2307 / 2065853$.

[12] F. D. Davis, "Perceived usefulness, perceived ease of use, and user acceptance of information technology," MIS Q., vol. 13, no. 3, pp. 319-340, 1989, https://doi.org/10.2307/24 $\underline{9008}$.

[13] V. Venkatesh, M. Morris, G. Davis, and F. Davis, "User acceptance of information technology: Toward a unified view,” MIS Q., vol. 27, no. 3, pp. 425-478, 2003, https://doi.org/ $10.2307 / 30036540$.

[14] I. Ajzen, "From Intentions to Actions: A Theory of Planned Behavior," in Action Control, Springer Berlin Heidelberg, 1985, pp. 11-39. https://doi.org/10.1007/978-3-642-69746$\underline{32}$

[15] W. R. King and J. He, "A meta-analysis of the technology acceptance model," Inf. Manag., vol. 43, no. 6, pp. 740-755, 2006, doi: 10.1016/j.im.2006.05.003.

[16] B. A. Kumar and S. S. Chand, "Mobile learning adoption: A systematic review," Educ. Inf. Technol., vol. 24, no. 1, pp. 471-487, 2019, doi: 10.1007/s10639-018-9783-6.

[17] V. Venkatesh and H. Bala, "Technology acceptance model 3 and a research agenda on interventions,” Decis. Sci., vol. 39, no. 2, pp. 273-315, 2008, https://doi.org/10.1111/j.15405915.2008.00192.x.

[18] C. Zhang et al., "Research on adoption of mobile virtual community in China and Korea," in 9th International Conference on Mobile Business and Global Mobility Roundtable, 2010, pp. 220-229, https://doi.org/10.1109/icmb-gmr.2010.8.

[19] N. Al-Qaysi, N. Mohamad-Nordin, and M. Al-Emran, "Factors Affecting the Adoption of Social Media in Higher Education: A Systematic Review of the Technology Acceptance Model," in Recent Advances in Intelligent Systems and Smart Applications, Springer, 2020, pp. 571-584. https://doi.org/10.1007/978-3-030-47411-9_31

[20] N. Al-Qaysi, N. Mohamad-Nordin, and M. Al-Emran, "Employing the technology acceptance model in social media: A systematic review," Educ. Inf. Technol., pp. 1-42, 2020, https://doi.org/10.1007/s10639-020-10197-1. 
[21] Y. Liu, S. Han, and H. Li, "Understanding the factors driving m-learning adoption: A literature review," Campus-Wide Inf. Syst., 2010, doi: 10.1108/10650741011073761.

[22] S. H. Chang, C. H. Chou, and J. M. Yang, "The literature review of technology acceptance model: A study of the bibliometric distributions," 2010.

[23] S.-C. Chen, S.-H. Li, and C.-Y. Li, "Recent Related Research in Technology Acceptance Model: A Literature Review," Aust. J. Bus. Manag. Res., 2011.

[24] L. Shuib, S. Shamshirband, and M. H. Ismail, “A review of mobile pervasive learning: Applications and issues,” Comput. Human Behav., 2015, doi: 10.1016/j.chb.2015.01.002.

[25] C. X. Navarro, A. I. Molina, and M. A. Redondo, "Factors influencing students' acceptance in m-learning: A literature review and proposal of a taxonomy," 2016, https://doi. org/10.1109/siie.2016.7751840.

[26] B. Kitchenham and S. Charters, "Guidelines for performing systematic literature reviews in software engineering," Softw. Eng. Group, Sch. Comput. Sci. Math. Keele Univ., pp. 157, 2007, doi: 10.1.1.117.471.

[27] W.-H. Wu, Y.-C. J. Wu, C.-Y. Chen, H.-Y. Kao, C.-H. Lin, and S.-H. Huang, "Review of trends from mobile learning studies: A meta-analysis," Comput. Educ., vol. 59, no. 2, pp. 817-827, 2012.

[28] R. A. Al-Maroof and M. Al-Emran, "Research Trends in Flipped Classroom: A Systematic Review," in Recent Advances in Intelligent Systems and Smart Applications, Springer, 2021, pp. 253-275. https://doi.org/10.1007/978-3-030-47411-9_15

[29] K. Al-Saedi, M. Al-Emran, E. Abusham, and S. A. El_Rahman, "Mobile Payment Adoption: A Systematic Review of the UTAUT Model," 2019. https://doi.org/10.1109/icfir.20 19.8894794

[30] D. Moher et al., "Preferred reporting items for systematic reviews and meta-analyses: The PRISMA statement," PLoS Medicine. 2009, https://doi.org/10.7326/0003-4819-151-4200908180-00135.

[31] F. Abdullah and R. Ward, "Developing a General Extended Technology Acceptance Model for E-Learning (GETAMEL) by analysing commonly used external factors," Comput. Human Behav., vol. 56, pp. 238-256, 2016, https://doi.org/10.1016/j.chb.2015.11.036.

[32] M. Al-Emran, V. Mezhuyev, and A. Kamaludin, "PLS-SEM in Information Systems Research: A Comprehensive Methodological Reference," in 4th International Conference on Advanced Intelligent Systems and Informatics (AISI 2018), 2018, pp. 644-653. https://doi. org/10.1007/978-3-319-99010-1_59

[33] M. K. Malhotra and V. Grover, "An assessment of survey research in POM: From constructs to theory,” J. Oper. Manag., vol. 16, no. 4, pp. 407-425, 1998, doi: 10.1016/S02726963(98)00021-7.

[34] G. J. Hwang and C. C. Tsai, "Research trends in mobile and ubiquitous learning: A review of publications in selected journals from 2001 to 2010," Br. J. Educ. Technol., vol. 42, no. 4, pp. E65-E70, 2011, https://doi.org/10.1111/j.1467-8535.2011.01183.x.

[35] Statista, "Share of mobile phone users that use a smartphone in China from 2013 to 2019," Statista, 2019. https://www.statista.com/statistics/257045/smartphone-user-penetration-inchinal.

[36] J. E. Bartlett, J. W. K. J. W. Kotrlik, and C. Higgins, "Organizational Research: Determining Appropriate Sample Size in Survey Research,” Inf. Technol. Learn. Perform. J., vol. 19, no. 1, pp. 43-50, 2001.

[37] S. A. Salloum, A. Q. M. Alhamad, M. Al-Emran, A. A. Monem, and K. Shaalan, "Exploring Students' Acceptance of E-Learning Through the Development of a Comprehensive Technology Acceptance Model," IEEE Access, vol. 7, pp. 128445-128462, 2019, https:// doi.org/10.1109/access.2019.2939467. 
[38] R. V Krejcie and D. W. Morgan, "Determining sample size for research activities," Educ. Psychol. Meas., vol. 30, no. 3, pp. 607-610, 1970, doi: 10.1177/001316447003000308.

[39] E. Erdfelder, F. FAul, A. Buchner, and A. G. Lang, "Statistical power analyses using G*Power 3.1: Tests for correlation and regression analyses," Behav. Res. Methods, 2009, https://doi.org/10.3758/brm.41.4.1149

\section{Authors}

Rawan A. Alsharida is working as an instructor in the Department of Computer Science, Tikrit University, Iraq. Her current research interests include mobile learning and technology acceptance.

Maytham M. Hammood is an Associate Professor in the Department of Computer Science, Tikrit University, Iraq. His current research interests include computer security and technology acceptance.

Mostafa Al-Emran is currently working in the Faculty of Engineering \& IT at The British University in Dubai, UAE. He obtained his Ph.D. degree in Computer Science from Universiti Malaysia Pahang. He received the MSc degree in Informatics from The British University in Dubai with a distinction level along with the top Academic Excellence Award and the BSc degree with honors in Computer Science from Al Buraimi University College. He has published over 70 research articles, and his main contributions have appeared in highly reputed journals, such as Computers \& Education, Computers in Human Behavior, International Journal of Information Management, Telematics and Informatics, IEEE Access, Technology in Society, Journal of Enterprise Information Management, Interactive Learning Environments, Journal of Educational Computing Research, and International Journal of Engineering Education, among many others. Most of his publications were indexed under the ISI Web of Science and Scopus. He has edited a number of books published by Springer. He is also a certified recognized reviewer by several leading journals in Elsevier. His current research interests include mobile learning, knowledge management, technology acceptance, wearable technology, and machine learning.

Article submitted 2020-08-27. Resubmitted 2020-10-25. Final acceptance 2020-10-26. Final version published as submitted by the authors. 